UDC 347.447 .63

DOI:10.5937/RKSPP1901011F

BÉNÉDICTE FAUVARQUE-COSSON

\title{
DOES REVIEW ON THE GROUND OF IMPRÉVISION BREACH THE PRINCIPLE OF THE BINDING FORCE OF CONTRACTS?
}

One of the striking features of the French reform is the introduction of revision and termination for unforeseeable changes of circumstances - imprévision. The aim of the new provision was to encourage parties to agree rather than bring the matter before the court for termination or for judicial revision for imprévision. Although courts have a general power to review the contract, the Court of Cassation relied on the principle of the binding force of contracts to justify the rejection of 'judicial review for imprévision'. Thus, the paper will elaborate whether the courts will seize the powers finally given to them - a power of revision. Furthermore, the drafting history of imprévision and the comparison between similar provisions in other international sources of law will be presented, as well as the relevant courts' practice.

Key words: Imprévision, Unforeseeable changes of circumstances, Force majeure, Hardship, Judicial review

\section{INTRODUCTION}

One of the striking features of the French reform of contract law (Ordonnance $\mathrm{n}^{\circ}$ 2016-131 of 10 February 2016) is the introduction into French law of revision and termination for imprévision - unforeseeable changes of circumstances. ${ }^{1}$ In 1804, without serious debate on the subject, the drafters of the Code civil chose to ignore the rule rebus sic stantibus invented by the canon lawyers to

Bénédicte Fauvarque-Cosson, Conseil d'Etat, Conseillère d'Etat, Agrégée des Facultés de droit and former professor at the University Panthéon Assas, Paris 2, e-mail: benedicte.fauvarque-cosson@conseil-etat.fr. 
allow the termination of the contract in the case of changed circumstances. The Cour de cassation then relied on the principle of the binding force of contracts to justify the rejection of 'judicial review for imprévision.2 140 years after the famous Canal de Craponne decision of the Cour de cassation, it will no longer be possible, on this point, to relate French law to English law on the basis that they both refuse judicial review for imprévision but knows the doctrine of frustration; nor to continue to contrast French law with German law which, on the contrary, recognises it. ${ }^{3}$

In the French reform, there was neither slavish copying, nor the 'myth of the foreign legislator, ${ }^{4}$ nor acculturation or intrusion of European law. Article 1195 is one of the most striking illustrations of the phenomena of hybridization across legal families and is also a testimony to legal pluralism within Europe. It draws its inspiration from the European and international environment, whilst differentiating itself from them in several respects.

The question of the power of the court to review contracts is a major subject of contract law. Not only does it form part of substantive debates about the powers of judges in society, and more specifically in contract law - while the Avant-projet Catala rejected the court's power to revise the contract, ${ }^{5}$ the Avantprojet Terré, by contrast, accepted it, after requiring the parties to renegotiate ${ }^{6}$

1 On this innovation, $\mathrm{cf}$ the various different commentaries on the reform, too numerous for them all to be cited here. See esp Olivier Deshayes, Thomas Genicon and Yves-Marie Laithier, Réforme du droit des contrats, du régime général et de la preuve des obligations. Commentaire article par article, Lexis Nexis, Paris, 2016, 384, who see in this a 'flagship provision of the Ordonnance' and a 'genuine break' within private law; François Chénédé, Le nouveau droit des obligations et des contrats. Consolidations. Innovations. Perspectives, Dalloz, Paris, 2016, 25.51, for whom it is 'one of the greatest innovations of the reform'

2 Decision of the Cour de cassation of 8 March 1876, Canal de Craponne: 'in no case shall it be for the courts, however fair their decision may seem, to take into account the passage of time and circumstances in order to modify the parties' contracts and to substitute new clauses for those which were freely accepted by the contracting parties'; cf French administrative law since the celebrated decision of the Conseil d'Etat of 30 March 1916, Gaz de Bordeaux: for administrative contracts, the Conseil d'État admits that the court has the power to terminate the contract or to award an indemnity to the party who is financially disadvantaged.

3 Konrad Zweiger, Hein Kötz, An Introduction to Comparative Law, 3rd edn, Clarendon Press, Oxford, 1998, 533.

4 In the famous expression of Carbonnier, in Jean Carbonnier, Essais sur les lois, Defrénois, Paris, 1979, 201; see also Jean Carbonnier, Droit civil. Introduction, 27th edn, PUF, Paris, 2002.

5 cf below fn 10 .

6 Art. 92 of Avant-projet Terré: 'The parties are bound to fulfill their obligations even if their performance has become more onerous. However, the parties must renegotiate so as to adapt or terminate the contract where its performance becomes excessively onerous for one of them as a 
but it is also at the heart of the debates on the respective places of the principles of contractual freedom, the binding force of contracts and contractual justice both in French law and in comparative law.

As already noted by Denis Tallon in 1984, in concluding an important study of comparative law, 'The principle of the binding force of contracts has lost its dogmatic foundation with the decline of the autonomy of the will. And the argument of uncertainty is not confirmed: in legal systems that admit judicial review for imprévision, it has not been reported that a multiplication of claims has crea-

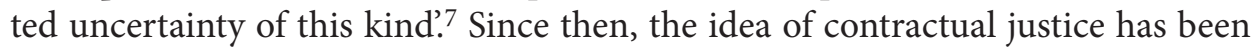
developing. It can be seen as a manifestation of the development of a wider phenomenon: the taking into account of ethics in the life of business. ${ }^{8}$ The traditional conception of the judge, a simple servant of the contract, gives way to a new 'contractual morality' based on good faith and fairness. ${ }^{9}$

The legislative and judicial qualifications which have developed in French law have shown the limits of the approach based on the principle of the binding force of contracts to say that it is for the parties to anticipate risks and not for the court to rebalance their contract. ${ }^{10}$ In times of economic and financial crisis, the difficulties encountered by certain economic operators due to contracts whose effects last over a long period have shown the importance of a fair distribution of contractual risk. In the situations where legislative provisions already take acco-

result of an unforeseeable change of circumstances and that party did not agree to assume that risk at the conclusion of the contract. In the absence of agreement between the parties within a reasonable time, the court may adapt the contract to the legitimate expectations of the parties or terminate the contract on the date and under the conditions it may fix'.

7 Denis Tallon, 'Réflexions comparatives', in La modification du contrat au cours de son exécution en raison de circonstances nouvelles, René Rodière (ed), Pedone, Paris, 1984, 194.

8 See esp the work of Professor Christopher Hodges and his report Ethical Business Regulation: Understanding the Evidence, www.gov.uk/government/uploads/system/uploads/attachment_ data/file/49, 15.08.2019.

9 cf Gaël Chantepie and Mathias Latina, La réforme du droit des obligations. Commentaire théorique et pratique dans l'ordre du Code civil, Dalloz, Paris, 2016, 443 ('The traditional conception, which forbids the court from interfering in the contract, is twisted round-expressed in such careful terms that it emerges as reinforced truth').

10 Even the Avant-projet Catala had opened a door-although a narrow one, its arts. 11352 et 1135-3 contemplating a relaxation of the rules governing the treatment of imbalance occurring during performance of the contract: see art. 1135-2: 'In the absence of such an express term, a party for whom a contract loses its point may apply to the President of the tribunal de grande instance to order a new negotiation'; art. 1135-3: 'Where applicable, these negotiations should be governed by the rules provided by Chapter I of the present Title. In the absence of bad faith, the failure of the negotiations gives rise to a right in either party to terminate the contract for the future at no cost or loss' 
unt of imprévision, ${ }^{11}$ these texts continue to apply and the new general rule of article 1195 will not apply, pursuant to article 1105(3) Cc (according to which ' $t$ t]he general rules are applied subject to these particular rules'), although this will not preclude the general rule serving as a source of inspiration to supplement or clarify a special legislative provision.

Between the binding force of contracts and contractual justice, would the scale tilt firmly to contractual justice? It seems not. In this respect, we should recall the mechanism of article 1195, which takes place in several stages. The first paragraph of article 1195 defines the conditions for its application and authorises one party to ask the other for renegotiation (without this producing any suspensive effect). The second paragraph of article 1195 deals first with the case where the parties jointly claim for the termination of their contract (a right which the parties already possess under article 1193, former article 1134(2)) or its judicial adaptation. ${ }^{12}$ The Report to the President of the Republic ${ }^{13}$ explains that the rules for imprévision are intended to 'play a preventive role: the risk of destruction or revision of the contract by the court should encourage the parties to negotiate. ${ }^{14}$ In fact, everything was planned in order to encourage the parties to agree rather than bring the matter before the court for termination or for judicial revision for imprévision. Article 1195 thus falls not only within the main-stream of the comparative law of contracts, ${ }^{15}$ but also at the heart of a major movement in relation to the civil process, in France and elsewhere, which develops and promotes alternative means of dispute resolution (compulsory amicable dispute resolution, participatory procedure agreements, etc).

On the other hand, the place of article 1195 in the Code civil bears a very French trademark. This provisionis the third article in Chapter IV on 'The Effects of Contracts. ${ }^{16}$ The principle of binding force of contracts having been moved up

11 See art. L 131-5 Code of Intellectual Property; art. 828 and art. 900-2 Code civi-1 .

12 See art. 12(4) Code of Civil Procedure: by common accord, the parties confer a task on the court: to decide as amiable compositeur. Here, by common accord, they request the court to terminate or adapt the contract.

${ }^{13}$ Rapport au Président de la République relatif à l'ordonnance $n^{\circ}$ 2016-131 du 10 février 2016 portant réforme du droit des contrats, du régime général et de la preuve des obligations, available at www.legifrance.gouv.fr, 15.08.2019.

14 ‘... jouer un rôle préventif, le risque d’anéantissement ou de révision du contrat par le juge devant inciter les parties à négocier'.

15 The idea of favor contractusis also present, not only in accepting judicial adaptation, but also through encouraging renegotiation.

16 Section 1 'The Effects of Contracts between the Parties', Sub-section 1 'Binding Force'. 
to the 'Introductory Provisions' of Chapter $\mathrm{I},{ }^{17}$ only the title of this Sub-section refers to this 'binding force', even though that is what it is devoted to. This is unfortunate, not only because of the lack of authority accorded to the titles of sections or sub-sections in the process of interpreting a legislative text, but also because this overall design does not allow the relationship between the principle (the binding force of contracts) and its exception (revision or termination for imprévision) to be brought out. Yet the fact that article 1195 derogates from the binding force of contracts is not expressly referred to either by article 1195 itself or by the two preceding articles (former articles $1134(2)$ and $1135 \mathrm{Cc}$ ). ${ }^{18}$

By contrast, in both the PECL and the UNIDROIT Principles, the binding force of contracts and change of circumstances or 'hardship' form an indivisible whole. Article 6:111 PECL, entitled 'Change of Circumstances', begins with a paragraph (1) which states: 'A party is bound to fulfil its obligations even if performance has become more onerous, whether because the cost of performance has increased or because the value of the performance it receives has diminished'. Significantly, article 6:111(2) begins 'If, however, .... Thus, the obligation to renegotiate and the power of the court to revise or terminate the contract in the absence of agreement by the parties are exceptions to the principle of binding force, expressly recalled in the text of Article 6:111.

In the UNIDROIT Principles, the "hardship'19 section is composed of three articles. The first, entitled 'Contract to be observed', begins by recalling that the parties are 'bound to perform [their] obligations' (article 6.2.1). ${ }^{20} \mathrm{~A}$ definition of

17 Art. 1103: 'Contracts which are lawfully formed have the binding force of legislation for those who have made them'.

18 Art. 1193: 'Contracts can be modified or revoked only by the parties' mutual consent or on grounds which legislation authorises.' Art. 1194: 'Contracts create obligations not merely in relation to what they expressly provide, but also to all the consequences which are given to them by equity, usage or legislation.' The reference to equity at the end of art. 1194 might even lead the interpreter to take some distance more easily from the principle of the binding force of contracts. To avoid this, it would have been helpful to introduce, at the beginning of art. 1195, the equivalent of art. 6:111(1) PECL: 'A party is bound to fulfil its obligations even if performance has become more onerous, whether because the cost of performance has increased or because the value of the performance it receives has diminished'. This would also have emphasized the criterion of 'excessive onerousness', a factor which justifies invoking article 1195 in order to seek adaptation or termination. See art. 92 Avant-projet Terré, above fn 6.

19 The term 'hardship' is not translated in the French version of the UNIDROIT Principles.

20 cf art. III.-1:110 Draft Common Frame of Reference (DCFR), which follows a very similar structure: 'III.-1:110: Variation or termination by court on a change of circumstances: (1) An obligation must be performed even if performance has become more onerous, whether because the cost of performance has increased or because the value of what is to be received in return has di- 
'hardship' is then given, which in fact serves to lay down the conditions for its application. It is in article 6.2.3 that its effects are defined, with, first, the opening of renegotiations and then, failing agreement by the parties, the following power granted to the court by article 6.2.3(4):

'If the court finds hardship it may, if reasonable,

(a) terminate the contract at a date and on terms to be fixed, or

(b) adapt the contract with a view to restoring its equilibrium.'

Article 1195, which is composed of only two paragraphs (compare Article 6:111 PECL which, for the reasons set out above, contains three), provides:

'If a change of circumstances that was unforeseeable at the time of the conclusion of the contract renders performance excessively onerous for a party who had not accepted the risk of such a change, that party may ask the other contracting party to renegotiate the contract. The first party must continue to perform his obligations during renegotiation.

In the case of refusal or the failure of renegotiations, the parties may agree to terminate the contract from the date and on the conditions which they determine, or by a common agreement ask the court to set about its adaptation. In the absence of an agreement within a reasonable time, the court may, on the request of a party, revise the contract or put an end to it, from a date and subject to such conditions as it shall determine.'

At first, the Chancellerie did not wish to allow the court to adapt the contract (except in the case of a joint request by the parties) and granted the court, in the absence of agreement between the parties, only a power to terminate the contract from a date and subject to such conditions as it should determine. Under article 1195 as enacted, this power of termination is maintained and a power of revision added. The fact that the court can either revise or terminate the contract, in both cases 'from a date and subject to such conditions' as it shall determine, sho-

minished. (2) If, however, performance of a contractual obligation or of an obligation arising from a unilateral juridical act becomes so onerous because of an exceptional change of circumstances that it would be manifestly unjust to hold the debtor to the obligation a court may: (a) vary the obligation in order to make it reasonable and equitable in the new circumstances; or (b) terminate the obligation at a date and on terms to be determined by the court. (3) Paragraph (2) applies only if: (a) the change of circumstances occurred after the time when the obligation was incurred; (b) the debtor did not at that time take into account, and could not reasonably be expected to have taken into account, the possibility or scale of that change of circumstances; (c) the debtor did not assume, and cannot reasonably be regarded as having assumed, the risk of that change of circumstances; and (d) the debtor has attempted, reasonably and in good faith, to achieve by negotiation a reasonable and equitable adjustment of the terms regulating the obligation.' 
uld have an even greater deterrent effect for the party that would have the greatest interest in maintaining the contract as it is, and this would thereby encourage renegotiation.

Judicial revision will be all the easier to implement, and therefore justified, in that the court will have simple instruments to carry it out. ${ }^{21}$ It will often be preferable to termination, not only for the debtor but for the whole spectrum of contracting parties who depend on the smooth running of contracts that are threatened to disappear. ${ }^{22}$ The recent European codifications establish, if not a hierarchy between revision and termination, at least an order of preference. This emerges, albeit rather elliptically, from article III.-110(2) DCFR ${ }^{23}$ or from article 89 CESL, which place judicial revision first before the power of the court to terminate the contract.

Could a court which is seized of a aclaim for revision terminate the contract, and vice versa? At first glance, the principle according to which it is for the parties to determine the subject-matter of civil litigation (le principe dispositive) seems to prohibit it. ${ }^{24}$ However, more flexible approaches would be possible. One is to distinguish between the case where the claim comes from both parties (in which case the court's power derives from the parties and it can only act within the limits of the principe dispositive, article 4 of the Code of Civil Procedure) or from only one of the parties, which could give it more latitude. ${ }^{25}$ The other is to consider that, for the operation of article 1195, the principe dispositif does not apply in 'all its rigour. ${ }^{26}$ This approach seems all the more appropriate since, in practice, the fact that the court can terminate the contract 'from a date and subject to such conditions as it shall determine' gives it so much freedom that the

${ }^{21} \mathrm{Eg}$. an index by which to index the price of a raw material if the parties had not done it.

22 See Nicolas Molfessis, 'Le rôle du juge en cas d'imprévision dans la réforme du droit des contrats, Libres propos', Juris-Classeur Périodique(JCP), no. 1415, 1995; Mauricio Almeida Prado, 'Regards croisés sur les projets de règles relatifs à la théorie de l'imprévision en Europe', Revue internationale de droit comparé (RIDC), 2010, 863.

${ }^{23}$ In 2010, the members of the Expert Group appointed by the Commission on the Common Frame of Reference met stakeholders and stressed that adaptation should be provided as an alternative to the possibility of terminating the contract, which should take place only as a last resort if the contract could not reasonably be maintained: see European Commission, Synthesis of the Sixth Meeting, 28-29 October 2010.

${ }^{24}$ Cf G. Chantepie, M. Latina, 450; O. Deshayes, T. Genicon, Y-M. Laithier, 412.

25 See Thierry Revet, 'Le juge et la révision du contrat', Revue des contrats (RDC), 2016, 373, esp 378; N. Molfessis, above fn 22.

${ }^{26}$ Philippe Malaurie, Laurent Aynès and Philippe Stoffel-Munck, Droit des obligations, 8th edn, LDGJ, Paris, 2016, 764. 
boundary with 'revision' becomes blurred. If it terminates the contract and makes a significant award of damages to the claimant, is this not also a form of indirect revision of the contract, the objective being to restore the initial balance that has been lost as a result of the change of circumstances? ${ }^{27}$

As for 'revision' itself, there is a question whether it extends only to financial conditions or whether, in a broader sense, it could lead to other consequences, thus approaching the 'adaptation' of the contract authorised by article 1195 for the situation where the parties have requested it of the court by common agreement. If semantic rigor should suggest that we should see the use of two different terms in article 1195 as requiring us to to distinguish between two different situations (the one in which there is a common agreement and the one where there is none) in practice, the distinction between 'adaptation' and 'revision' is difficult to make.

After a reminder of the various steps which lead up to article 1195 as enacted, the links between article 1195 and other contract law issues will be examined in the light of the reform as a whole and comparative law.

\section{ARTICLE 1195: THE OUTCOME OF A LONG PROCESS}

The report to the President of the Republic, numerous academic commentaries and the various phases of the reform marked by several drafts constitute the travaux préparatoires missing from this reform given that it was made by Ordonnance. It is these that elucidate the new article 1195 of the Code civil. On the other hand, external insights from practice and comparative law show that courts in their wisdom are very cautious in their use of powers similar to those conferred by article 1195, with the result that there is no reason to fear, as some people believe, that this text will make French law lose its attractiveness.

\section{From Article 136 of the 2008 Draft to Article 1195 of the Code Civil}

We cannot undertake here a literal study of each of them, or a comparison between these texts and those of other non-governmental projects, ${ }^{28}$ but the texts

27 It is true that the court which revises the contract and determines the date and conditions of the revision sets himself up as an ex post 'co-drafter of the contract' (see T. Revet, above fn25), which goes even further.

${ }^{28}$ For a deeper comparative analysis, see esp Philippe Stoffel-Munck, 'L'imprévision et la réforme des effets du contrat', RDC hors-série, 2016. 
of the previous drafts will be reproduced with, in bold type, the points which deserve attention in the light article 1195 as enacted..$^{29}$

Draft of July 2008, art. 136:

'If a change in circumstances that was unforeseeable and insurmountable renders performance excessively onerous for a party who had not accepted the risk of such a change, that party may ask the other contracting party for renegotiation but must continue to perform his obligations during renegotiation.

In the event of refusal or the failure of renegotiations, the court may, if the parties agree, set about the adaptation of the contract or, in the absence of agreement, put an end to it, from a date and subject to such conditions as it shall determine.'

Draft of February 2009, art. 101:

'If a change in circumstances that was unforeseeable renders performance excessively onerous for a party who had not accepted the risk of such a change, that party may ask the other contracting party for renegotiation but must continue to perform his obligations during renegotiation.

In the event of refusal or the failure of renegotiations, the court may set about the adaptation of the contract if the parties agree or, in the absence of agreement, put an end to it, from a date and subject to such conditions as it shall determine.'

Draft 2010 (Technical Group) version 8 October 2010, art. 119:

'If a change of circumstances that was unforeseeable at the time of the conclusion of the contract renders performance excessively onerous for a party who had not accepted the risk of such a change, that party may ask the other contracting party for renegotiation. The first party must continue to perform his obligations during renegotiation.

In the event of refusal or the failure of renegotiations, the court may set about the adaptation of the contract if the parties agree. In the absence of agreement, it may put an end to it, from a date and subject to such conditions as it shall determine.'

Minister's group draft 16 February 2011, art. 117 (Change of Circumstances):

${ }^{29}$ On the different stages in the reform, and for an analysis by insiders of these successive drafts from 2008 to 2015, see François Ancel, Bénédicte Fauvarque-Cosson, Juliette Gest, Aux sources de la réforme du droit des contrats, Dalloz, Paris, 2017. 
'If a change of circumstances that was unforeseeable at the time of the conclusion of the contract renders performance excessively onerous for a party who had not accepted the risk of such a change, that party may ask the other contracting party for renegotiation. The first party must continue to perform his obligations during renegotiation.

In the event of refusal or the failure of renegotiations, the parties may ask the court to set about the adaptation of the contract. In the absence of such common request, one party may ask the court to put an end to it, from a date and subject to such conditions as it shall determine.'

Draft of February 2015, art. 1196:

'If a change of circumstances that was unforeseeable at the time of the conclusion of the contract renders performance excessively onerous for a party who had not accepted the risk of such a change, that party may ask the other contracting party for renegotiation. The first party must continue to perform his obligations during renegotiation.

In the event of refusal or the failure of renegotiations, the parties may by a common agreement ask the court to set about the adaptation of the contract. In the absence of such common request, one party may ask the court to put an end to it, from a date and subject to such conditions as it shall determine.'

\section{External Insights}

Reactions of the CCI Paris Ile-de-France. - Amongst the organizations representing businesses, the Chambre de commerce etd'industrie (CCI) Paris Ile-deFrance has been heavily involved since 2005 to put forward the voice of business. In various reports, it noted that not all businesses have the benefit of legal services sufficient to incorporate suitable clauses systematically into their contracts. It also stressed the paradox faced by economic operators caught between, on the one hand, the desire for contractual stability and legal certainty and, on the other hand, the desire for greater flexibility and adaptability in the face of economic developments, and of the fact that contractual relations are themselves becoming more and more long-term.

In 2008, the CCI Paris Ile-de-France proposed the introduction of an obligation to renegotiate the contract on the occurrence of a change of circumstances which satisfies strict conditions and, in the event of failure of the renegotiations, 
to grant the court the power to adapt the contract, upon referral by either party, on the basis (as it said) of the 'legitimate expectations of the parties.' ${ }^{30}$

In its report following the consultation opened by the Chancellerie on the draft Ordonnance of 2015, the CCI Paris Ile-de-France, which then took for granted the requirement of the prior common agreement of the parties as a condition of revision by the court, suggested that judicial adaptation should be framed by reference to the criteria of 'legitimate expectations of the parties' and the usage and practice of the market. It made clear that judicial termination for imprévision should be only one 'powerof the court. ${ }^{31}$

European Inspiration. - The report to the President of the Republic stresses the importance of the European context: 'France is one of the last European countries not to recognize the theory of imprévision as a factor moderating the binding force of contracts. Its formal recognition, which is inspired by comparative law as well as by the European harmonisation projects, makes it possible to combat the major contractual imbalances which occur during performance, in accordance with the objective of contractual justice pursued by the Ordonnance.'

As regards these 'European harmonisation projects' we can mention, in addition to the PECL and the DCFR, article 89 CESL, entitled 'Change of circumstances', which allows the court to adapt the contract upon request by one of the parties (see article 89.2(a)), CESL, under certain well-defined conditions (see article $89.3 \mathrm{CESL}$ ). ${ }^{32}$ Adaptation is even placed ahead of termination, which is not purely accidental but attests to a spirit already perceptible in international trade

30 See www.cci-paris-idf.fr/sites/default/files//etudes/wysiwyg/PDF/reforme-droit-des-contrats-kli0810.pdf, 15.08.2019.

31 See www.cci-paris-idf.fr/sites/default/files/etudes/pdf/documents/reforme-droit-des-contrats-fou1505.pdf, proposition no 6, 15.08.2019.

32 Proposal for a Regulation of the European Parliament and of the Council on a Common European Sales Law $\operatorname{COM}(2011)$ 635, 11.10.2011, art. 89: '1. A party must perform its obligations even if performance has become more onerous, whether because the cost of performance has increased or because the value of what is to be received in return has diminished. Where performance becomes excessively onerous because of an exceptional change of circumstances, the parties have a duty to enter into negotiations with a view to adapting or terminating the contract. 2 . If the parties fail to reach an agreement within a reasonable time, then, upon request by either party a court may: (a) adapt the contract in order to bring it into accordance with what the parties would reasonably have agreed at the time of contracting if they had taken the change of circumstances into account; or (b) terminate the contract within the meaning of Article 8 at a date and on terms to be determined by the court. 3. Paragraphs 1 and 2 apply only if: (a) the change of circumstances occurred after the time when the contract was concluded; (b) the party relying on the change of circumstances did not at that time take into account, and could not be expected to have taken into account, the possibility or scale of that change of circumstances; and (c) the aggrieved party did not assume, and 
law: the favor contractus, or preference for the preservation of the contract, which is no doubt considered more important for the development of the internal market than absolute respect for the principle of the binding force of contracts.

Judicial revision for imprévision made its entry into Belgium, first by resorting to the notion of abuse of rights, ${ }^{33}$ then, and with international significance, by interpreting article 79(1) CISG in the light of the UNIDROIT Principles.

Article 79(1) CISG, which specifies the situations in which non-performance is excused (article 79 is headed 'Exemptions'), makes no reference to changes of circumstances. In the face of this silence, at first a restrictive interpretation prevailed. ${ }^{34}$ However, the first Civil chamber of the Belgian Cour de cassation, in a bold judgment of 19 June 2009, adopted a 'creative' interpretation of article 79 CISG, declaring that: ${ }^{35}$

'With regard to contracts for the international sale of goods, changed circumstances which were not reasonably foreseeable at the conclusion of the contract and which are undoubtedly of such a nature as to increase the burden of performance of the contract may, in certain cases, constitute an impediment independent of its will exempting the party from liability for non-performance of one of its obligations.'

cannot reasonably be regarded as having assumed, the risk of that change of circumstances. 4 . For the purpose of paragraphs 2 and 3 a 'court' includes an arbitral tribunal.'

33 See eg. the many decisions on revision of maintenance payments: Philippe Denis, Changement de circonstances et bouleversement de l'économie contractuelle, Bruylant, Bruxelles, 1986; Philippe Denis, 'Le bouleversement de l'économie contractuelle en droit belge', Revue de Droit International et de Droit Comparé (RDIDC), no 2, 2015, 159.

34 For summaries of decisions unfavourable to the theory of imprévision see www.cisg.law. pace.edu, 15.08.2019; Vincent Heuzé, La vente internationale de marchandises, LGDJ, Paris, 2000, esp 360, 468ff. In France, the Cour de cassation has held that 'the party must bear the risk of nonperformance without having recourse to art. 79 CISG if he does not establish the unforeseeable character of the modification of the conditions of sale where, as a professional experienced in the practice of international markets, it was for him to make provision for contractual mechanisms of guarantee or of revision': Decision of Cour de Cassation of 30 June 2004, no. 01-15964, D 2005, 2281, Claude Witz, 'Droit uniforme de la vente internationale de marchandises: panorama 2004, Recueil Dalloz, 2005, Panorama, 2289.

35 Decision of Cour de cassation of 19 June 2009, C.07.0289.N. On this decision, see esp. Denis Philippe, 'Renégociation du contrat en cas de changement de circonstances dans la venteinternationales', RDC, 2011, 963; C.Witz, 932; Denis Philippe, French and Belgian reports, in Unexpected Circumstances in European Contract Law, Ewoud Hondius, Hans C. Grigoleit (eds.), Cambridge University Press, Cambridge, 2011, 150. 
The Court added that 'the party to the contract who invokes such changed circumstances which fundamentally undermine the contractual balance also has a right to demand a new negotiation of the contract'.

This important judgment of the Belgian Cour de cassation has helped to reinforce the idea that imprévision is a general principle of international trade law. ${ }^{36}$

\section{IMPRÉVISION IN THE REFORM OF CONTRACT LAW: RELATED ISSUES}

\section{Imprévision and Force Majeure: What are the Differences?}

In contractual practice, there is sometimes confusion between force majeure clauses and clauses relating to a change of circumstances which causes 'hardship', often referred to as hardship clauses. In 2003, the International Chamber of Commerce published twin model forms, one for a force majeure clause and the other for a hardship clause, thus providing greater clarity in this area.

As a matter of law, there are a number of clear differences between imprévision and force majeure.

Conditions for Operation. - The conditions for the operation of force majeure differ from those required for imprévision: performance of the obligation must be 'prevented' (and therefore impossible) and not simply 'excessively onerous'. In this respect, it is interesting to note that article 136 of the July 2008 draft, which gave the court a power of revision or termination only 'if the parties agree, still required a change of circumstances that was both unpredictable and insurmountable. ${ }^{37}$

The new article 1218(1) of the Civil Code provides the following definition of force majeure:

'In contractual matters, there is force majeure where an event beyond the control of the debtor, which could not reasonably have been foreseen at the time of the conclusion of the contract and whose effects could not be avoided by appropriate measures, prevents performance of his obligation by the debtor.

36 M. Prado, 863; Alejandro Garro, 'Comparison between provisions of the CISG regarding exemption of liability for damages (Art. 79) and the counterpart provisions of the UNIDROIT Principles (Art. 7.1.7), www.cisg.law.pace.edu/cisg/principles/uni79.html,15.08.2019. For discussions on the CISG see Harry M. Flechtner, 'Transcript of a Workshop on the Sales Convention: Leading CISG scholars discuss Contract Formation, Validity, Excuse for Hardship, Avoidance, Nachfrist, Contract Interpretation, Parol Evidence, Analogical Application, and much more', Journal of Law \& Commerce, no. 18,1999, 191-258, and for recent developments in this area, see Catherine Kessedjian, Droit du commerce international, PUF, Paris, 2013, 256.

37 See www.cci-paris-idf.fr/sites/default/files//etudes/wysiwyg/PDF/reforme-droit-des-contrats-kli0810.pdf, 15.08.2019. 
In this definition, we find the three elements traditionally required for force majeure: exteriority, unforeseeability and irresistibility. ${ }^{38}$

It was surprising that, while article 1195 requires that the change incircumstances be unforeseeable, article 1218 on force majeure is limited to an event which could not 'reasonably' have been foreseen. ${ }^{39}$ Harmonizing the two provisions either by using the adverb 'reasonably' in article 1195 (to give an objective connotation to the test that the court will have to implement), or by deleting it from article 1218, would have been logical, even if, in practice, this would have had only a cosmetic function. In fact, with or without the adverb 'reasonably', the test for foreseeability leaves a large margin of appreciation to the court, ${ }^{40}$ except that in both cases the court must place itself 'at the time of the conclusion of the contract' when it makes that assessment. ${ }^{41}$

The comparison of the conditions for the operation of article 1195 with those of article 1218 on force majeure casts a greater light on this distinctive criterion of imprévision: 'excessive onerousness'. This criterion, taken from the PECL, was already contained in article 1467(1) of the Italian civil code of 1942 (eccessiva onerosità sopravvenuta), which applies it to the act of performance (la prestazione) and not to performance (lesecuzione) of the obligation: 'In contracts for continuing or periodic performance, or even for deferred performance, if the act of performance of one of the parties has become excessively onerous following the occurrence of extraordinary and unforeseeable events, that party may request termination of the contract, together with the effects provided for in article $1458 .^{\prime 42}$

The generally accepted idea is that the gap between what one party receives and what the other provides must be so great that a parallel is sometimes made, at least in the countries which admit it, with laesio enormis. ${ }^{43}$ A question which

38 cf the Report to the President of the Republic, which indicates that this definition requires only unforeseeability and irresistibility not exteriority. For further discussion, see F. Chénédé, 28.22.

39 G. Chantepie, M. Latina, 445.

40 Cf P. Stoffel-Munck, 33.

41 On the difficulties posed by this condition for contracts of definite duration with implied renewal clauses, in that it requires the court to place itself at the date of the last renewal, whereas the parties at each renewal will not have reconsidered their initial view, see P. Stoffel-Munck, 33; Jean-Daniel Bretzner, in Réforme du droit des contrats et pratique des affaires, Philippe StoffelMunck (ed.), Dalloz, Paris, 2015, 84.

42 Art. 1467(1) of the Italian civil code again requires that there should have been 'extraordinary and unforeseeable events': on this criterion, see O. Deshayes, T. Genicon, Y-M. Laithier, 385 and $394 \mathrm{ff}$.

${ }^{43}$ For a critical analysis of these criteria, which give the court a broad margin of appreciation, see P. Stoffel-Munck, 32ff. 
has arisen, particularly in the field of energy (for example, in sectors where pollution licences exist), is whether the excessively onerous nature is assessed not only in terms of costs, but also of the lost profits or, on the other hand, the unexpected profit which the other party has derived from the contract and from which has not been shared. ${ }^{44}$

Although the UNIDROIT Principles are limited merely to 'more onerous' performance (article 6.2.1), they require additionally that the events which occur 'fundamentally alter the equilibrium of the contract, either because the cost of a party's performance has increased or because the value of the performance a party receives has diminished' (article 6.2.2).

There is also another condition for the application of article 1195 which the court must establish: the risk must not have been assumed by the contracting party who claims under it. ${ }^{45}$

Effects and Non-mandatory Nature of the Legislative Provisions. - Force majeure permits the debtor not to perform his obligations. It is thus a genuine exemption from liability for the debtor. If the prevention is temporary, the obligation is suspended and, exceptionally, can be extinguished. If it is permanent, the contract is then 'terminated by operation of law'. Article 1218 therefore dispenses the debtor from applying to court, an approach which is consistent with solutions already adopted by a large number of European legal systems and is also close to the PECL and the UNIDROIT Principles. Above all, it draws the consequences of reforms introduced in this area, since termination for non-performance by notice is no longer treated as an exception to a general rule of termination by the court, but is instead 'treated as an independent power offered to the creditor'. 46

The non-mandatory nature of articles 1195 and 1218 allows the parties to modify or exclude the application of their provisions. As we have seen, in contractual practice 'adaptation clauses' and 'force majeure clauses' are very widespread. The reform did not aim to call this practice into question. The Ordonnance says nothing about the non-mandatory nature of these provisions, but this is explained by the Report to the President of the Republic. In principle clauses of this type are valid, but they must be drafted carefully, whether their aim is to exclude the operation of article 1195 (for example, by a clause in which one of the

44 On this debate, see T. Revet, 376; N. Molfessis, 1415.

45 On the influence of PECL on this, see F. Chénédé, 25.62. As the commentary on the UNIDROIT Principles also explains, the term 'assumed' indicates that it is not necessary that the risks have been allocated expressly, but this may follow from the nature of the contract itself (eg. a speculative venture).

46 F. Chénédé, 28.171. 
parties formally assumes the risk of changes of circumstances, a possibility which the text of course envisages), or to exclude the possibility of suspending or releasing the obligations of one of the parties in the event of force majeure (the contracting party undertakes to fulfil its obligations even in the event of force majeure - and the obligation de résultat becomes thereby an obligation de garantie ${ }^{47}$ ).

These clauses are valid in bespoke contracts, but they could become routine clauses, especially in standard form contracts and would therefore run the risk of falling within the scope of the controls of unfair terms in article 1171. This would be the case, for example, if a clause provided that only the undertakings of one of the parties, in this case the undertaking of the party who accepts the other's standard form, could not be excluded in case of force majeure. On the other hand, even in a standard form contract, a clause accepting the risk of an obligation becoming excessively onerous could be upheld on the ground that it relates to the adequacy of the price in relation to the act of performance (see art. 1171(2)). Finally, for all types of contracts, including bespoke contracts, such clauses could still be excluded on the basis of the controls on contract terms in Article L 442-6, I, 2 Ccom. ${ }^{48}$

In the 'Common Contractual Principles'49 drawn up on the basis of the PECL and proposing a revised version in the context of preparing a draft Common Frame of Reference requested by the European Commission, French academic writers proposed the addition, immediately after article 7:101 PECL on Change of Circumstances, of a provision on risk-sharing clauses that would have led to a result similar to what Article L 442-6 I 2 Ccom would allow:

'A clause which would apportion to one of the parties the essential risks of a change of circumstances is valid only if it does not entail unreasonable consequences for that party. The clause shall not be applied where the change in circumstances is attributable in whole or in part to the party for whose benefit it was stipulated.' 50

47 An 'obligation de résultat' is an obligation under which the debtor must achieve a particular result, but its non-performance is excused where performance is prevented by force majeure; an 'obligation de garantie' is an obligation where the debtor must achieve a result come what may, ie even if prevented from doing so by force majeure.

48 See P. Stoffel-Munck, 32ff.

49 Association Henri Capitant and Société de législation comparée, Projet de cadre commun de référence. Principes contractuels communs, Société de législation comparée, Paris, 2008.

50 Ibidem, art. 7:102. In the discussions at the Commission on the draft common European sales law, consumer representatives stressed that rules on change of circumstances should not be used against the interests of consumers, who are not in a position to negotiate. The experts replied 


\section{Imprévision and Contractual Groups}

Article 1186 Cc.-The acceptance of imprévision creates the risk of a chain reaction affecting other contracts, especially if it entails the termination as opposed to the mere adaptation of the contract. Often raised as a result of the economic crisis, this risk is acute in the context of contractual groups. This phenomenon is taken into account by article 1186(2),(3) Cc on the lapse of linked contracts, which provides that:

Art. 1186. - A contract which has been validly formed lapses if one of its necessary elements disappears.

Where the performance of several contracts is necessary for the putting into effect of one and the same operation and one of them disappears, those contracts whose performance is rendered impossible by this disappearance lapse, as do those for which the performance of the contract which has disappeared was a decisive condition of the consent of one of its parties.

However, lapse occurs only if the contracting party against whom it is invoked knew of the existence of the group operation when he gave his consent.'

This provision deals with the frequent phenomenon of the interdependence or indivisibility of contracts, and it will supply a new textual basis for earlier caselaw under which the nullity or termination of one of two or more interdependent contracts may lead to the extinction of its linked contracts, whose lapse has thus already been recognised. ${ }^{51}$ Neither the PECL nor the UNIDROIT Principles devote a general provision to 'linked contracts' or 'ancillary contracts'.

Some commentators on the French reform ask whether, owing to the numerous questions which arise, it was not 'premature' to codify case-law that was based on foundations that remain uncertain, and note that uncertainty persists even after the reform, particularly as regards the fate of severance clauses..$^{52}$ As regards the latter, it seems logical to admit their effectiveness in principle, 'in the name of the free distribution of risk between the parties. ${ }^{53}$

Towards an Obligation to Renegotiate in the Case of Contractual Groups?. Will the fact that the contract whose performance has become 'excessively one-

that it would be for the court to assess the circumstances and that putting the risk of a change of circumstances on the consumer alone would be an unfair term.

${ }^{51}$ Başak Başoğlu (ed), The Effects of Financial Crises in the Binding Force of ContractsRenegotiation, Rescission or Revision, Springer, Cham, 2016.

52 F. Chénédé, 23.491; and, on severance clauses, 23.497.

53 F. Chénédé, 23.497. 
rous', is part of a contractual group encourage courts to exercise the powers conferred on them by article 1195 even more cautiously? What safeguards could they put in place to avoid such chain reactions?

One avenue could be to impose on the parties an obligation to renegotiate as a precondition. This had been raised, but the legislator rejected it, influenced by the Cour de cassation which had pointed out that this would give rise to dispute as to the assessment of the good or bad performance of that obligation. In comparative law, there are considerable differences as regards the imposition of an obligation to renegotiate before judicial revision or termination for imprévision is allowed. The European (PECL) and international (UNIDROIT principles) models both require it. On the other hand, the new Restatement of Nordic Contract Law, published in 2016, contains an article 6-7 entitled 'Change of circumstances' which imposes no obligation to renegotiate before the court can intervene. ${ }^{54}$ In Dutch law, not only are the parties not subject to a renegotiation obligation, but one of them can even directly request the court to adapt the contract, with retroactive effect. ${ }^{55}$ Some authors have criticized this and suggested that a duty to renegotiate should be established on the basis of the general duty of reasonableness and fairness. ${ }^{56}$

While under article 1195 the parties are in principle free to refuse to renegotiate, nevertheless a refusal to do so which is found 'abusive' could be sanctioned, pursuant to article 1104 as a breach of its duty of good faith. One possible way to do this would be to consider that where the contract fits into a contractual group and the termination of the contract entails the lapse of the other contracts of the group, the parties must make special efforts to save the contract. If the renegotiation still fails, it would be for the court to prefer adaptation rather than termination of the contract insofar as only this would allow the survival of the other contracts.

Restitution -Following - Lapse of the Contract. - Where the contract lapses in the course of its performance, lapse does not take effect retroactively, but this does not prevent the operation of restitution. Thus, under article 1187, 'Lapse puts an end to the contract. It may give rise to restitution under the conditions

54 O Lando et. al. (eds), Restatement of Nordic Contract Law, Djof Publishing, Copenhagen, 2016, 221.

55 Art. 6:258 BW, in conjunction with art. 6:260.

56 Art. 6:248 BW. See Danny Busch, Ewoud Hondius, Hugo van Kooten, Harriët Schelhaas, Wendy Schrama (eds), The Principles of European Contract Law and Dutch Law, A Commentary, Kluwer Law International, The Hague, 2002, 289. 
provided by articles 1352 to 1352-9'. The appropriateness of restitution is therefore left to the assessment of the court.

In this respect, Chapter V of Title IV of the general regime of obligations is innovative, as this chapter on restitution brings together the main rules concerning restitution following the destruction of a contract, whether this results from annulment, lapse or retroactive termination (articles 1352 to 1352-9): it provides the general law of restitution. To this end, the established rules of law have been consolidated, in particular as regards the principle of restitution in kind (except for obligations of sums of money). However, three rules are new given the state of the earlier case-law. Thus, fruits must be restored irrespective of the good or bad faith of the person responsible for making restitution (article 1352-3); restitution includes the value of the enjoyment that the thing has provided; and finally and contrary to earlier case-law, restitutionin respect of the supply of a service is formally recognised and is stated as taking place by value, assessed at the date on which it was supplied (article 1352-8) and not according to the rules of unjustified enrichment (which implies taking the lesser of the two sums resulting from the impoverishment of one party and the enrichment of the other: article 1303).

From a Franco-English perspective, it is interesting to note that the doctrine of frustration leads to the termination of the contract and that restitutionis organised by section 1 of the Law Reform (Frustrated Contracts) Act 1943. The court seems to have a fair room for manoeuvre, because of the need to find the fairest solution. Could this not be seen as a form of judicial adaptation of the contract even if not expressed in this way?

\section{Imprévision and Non-performance in Perspective}

(Articles 1221 and 1224)

Article 1195 provides for intervention by the court only after a certain period has elapsed, in order to allow time for the negotiations to succeed. ${ }^{57}$ But what happens if the creditor immediately refuses to renegotiate on the ground that the debtor's claim is unfounded as the situation does not constitute a case of $\mathrm{im}$ prévision? This question cannot be answered without considering the relationship

57 The last phrase of art. 1195 (the most important, which gives the court its powers) opens in these terms: In the absence of an agreement within a reasonable time, the court may ... It has been questioned whether this is a drafting error: G. Chantepie, M. Latina, 445; or an indication of the intention of the legislator to impose preconditions, in a scheme which 'is similar to the clauses requiring prior conciliation or mediation, ignorance of which opens up the penalties of inadmissibility': T. Revet, 378. 
between Section I on the effects of contracts (and therefore article 1195) and Section V of Chapter IV on the effects of contracts (and in particular its two key articles, 1221 and 1224).

Article 1195 and Article 1221 (Enforced Performance). - The new article 1221 prohibits the creditor from seeking performance in kind if performance is impossible or if there is a manifest disproportion between its cost to the debtor and its interest for the creditor. ${ }^{58}$ Where a debtor who considers that the conditions of article 1195 are satisfied so as to establish a case of imprévision, but the creditor disagrees and refuses to renegotiate the contract, the debtor may wish to run the risk of the creditor bringing proceedings against him for enforcement under article 1221 so as then to counter that the change of circumstances means that there is a 'manifest disproportion' between the cost to him in performance and the interest of the creditor in enforcement. ${ }^{59}$

Here, a comparison with English law raises a few questions.

First, does the fact that specific performance is exceptional in English law make the development of a theory of imprévision less necessary? Indeed, since non-performance is sanctioned by damages, the court may fix their amount taking into account the circumstances and in particular the change of circumstances.

Secondly, does English law, which is said to reject judicial revision of the contract, never arrive at a result similar to that to which article 1195 may lead? ${ }^{60}$ The routes by which this revisionis achieved are clearly diverse, each with its own special features: the idea of 'frustration of purpose, ${ }^{61}$ misrepresentation, implied terms, force majeure or hardship clauses, etc.

Moreover, in English law, a party cannot invoke frustration where it is 'self-induced' (ie. caused by his own conduct). What is the use of this concept that has not been established in French law? On the other hand, frustration is gene-

58 Art. 1221: 'A creditor of an obligation may, having given notice to perform, seek performance in kind unless performance is impossible or if there is a manifest disproportion between its cost to the debtor and its interest for the creditor.'

${ }^{59}$ For an analysis of the links between litigation for imprévision and for non-performance, see O. Deshayes, T. Genicon, Y-M.Laithier, 418.

60 Horace Yeung, Flora Huang, 'Certainty over Clemency: English Contract Law in the Face of Financial Crisis', in The Effects of Financial Crises in the Binding Force of Contracts-Renegotiation, Rescission or Revision, Başak Başoğlu (ed), Springer, Cham, 2016, 285.

${ }^{61}$ Could the parties in advance forbid the court from applying the doctrine of frustration? 
rally invoked as a defence by a defendant who has not performed his obligation: what is the link with anticipatory breach (which is not admitted in French law ${ }^{62}$ )?

Under German law, something very close to imprévision is established by $\$$ 313 BGB, entitled 'Interference with the basis of the transaction.' ${ }^{63}$ Ten years after the entry into force of the German reform and the codification of this rule which was previously found only in case-law, it was established that courts used their power of intervention less often than previously, since the law, while formally recognising a power which the courts had imposed on the basis of good faith, had strictly defined its parameters. One limitation on the operation of $\$ 313$ BGB is that it only applies if $\$ 275 \mathrm{BGB}$, entitled 'exclusion of the duty of performance', is inapplicable. $\$ 275(1)$ BGB provides:

"A claim for performance is excluded to the extent that performance is impossible for the obligor or for any other person' and \$275(2) BGB states that:

"'The obligor may refuse performance to the extent that performance requires expense and effort which, taking into account the subject matter of the obligation and the requirements of good faith, is grossly disproportionate to the interest in performance of the obligee...

It is true that $\$ 275$ BGB applies very rarely in the case of substitutable goods because the debtor is supposed to do everything possible to fulfil his obligation, including such goods elsewhere. Moreover, contrary to $\$ 313$ BGB on interference with the basis of the transaction, $\$ 275$ BGB does not provide for the adaptation of the contract by the court.

To a certain extent, by prohibiting the creditor from seeking performance in kind where performance is impossible or where there is a manifest disproportion between its cost to the debtor and its interest for the creditor, article 1221 will provide an incentive to the creditor who has received a request to renegotiate wit-

62 On anticipatory breach, see Solène Rowan, The New French Law of Contract, Cambridge University Press, Cambridge, 2017.

63 Translation from $w w w . g e s e t z e-i m$-internet.de/englisch_bgb: (1) If circumstances which became the basis of a contract have significantly changed since the contract was entered into and if the parties would not have entered into the contract or would have entered into it with different contents if they had foreseen this change, adaptation of the contract may be demanded to the extent that, taking account of all the circumstances of the specific case, in particular the contractual or statutory distribution of risk, one of the parties cannot reasonably be expected to uphold the contract without alteration. (2) It is equivalent to a change of circumstances if material conceptions that have become the basis of the contract are found to be incorrect. (3) If adaptation of the contract is not possible or one party cannot reasonably be expected to accept it, the disadvantaged party may revoke the contract. In the case of continuing obligations, the right to terminate takes the place of the right to revoke. 
hin the framework of article 1195. For where the debtor relies on article 1195, article 1221, which the report to the President of the Republic explains that 'can be analysed as a variation on the principle of abuse of right', may well prompt the creditor to exercise extreme caution before requiring enforced performance where the debtor relies on article 1195.

Article 1195 and Article 1224 (Unilateral Termination). - A creditor who establishes non-performance by the other party may apply to the court for judicial termination, which will enable the court to decide whether or not there is a change in circumstances apt to trigger article 1195, and, if so, to decide whether or not to refer it back to the parties to agree on its consequences. From now on, the creditor may also terminate the contract unilaterally by notice (article 1224) at his own risk and in accordance with a procedure defined by article 1226 .

If the creditor prefers to terminate unilaterally for non-performance, the debtor can then apply to the court to challenge this (article 1226(4)) and then invoke the existence of an 'unforeseeable change of circumstances' justifying termination of the contract, but this time from a date and subject to such conditions as the court shall determine (article 1195, final words). ${ }^{64}$ If the court considers that the conditions for the application of article 1195 are fulfilled, it will uphold the termination of the contract and, if necessary, sanction the creditor. In theory, by combining the operation of article 1226 and article 1195, a court could even order the enforced continuation of the contract while at the same time adapting it to the changed circumstances so that the debtor can perform it without excessive onerousness. However, the Civil Code does not allow a court to adapt a contract in the absence of a change in circumstances, and as a result a court could not do so unless it considers that the conditions for the application of article 1195 are fulfilled (article 1228).

\section{CONCLUSION}

Judicial revision has made a remarkable entrance into the French general contract law but it is still too early to determine whether the courts will seize the powers thus given to them, in particular the power of revision. ${ }^{65}$

64 It is different where there is a termination clause: see F. Chénédé, 28.177.

65 An 'indirect' power of judicial revision is now even established by the articles of the Code civil relating to control of the remuneration of independent service providers: where the price has been fixed unilaterally and there has been abuse, the court 'may hear a claim for damages': art. 1165; T. Revet, above n 25. 
With article 1195, a new conception of the role of the court has appeared in the Civil Code, inspired by national, European and international models. In the current international context which is marked by a certain rivalry between legal families, particularly those of the common law and continental law, the imperative of legal certainty, here understood as requiring the preservation of the stability of contractual relations, is often put at the forefront. If French courts bear this imperative clearly in mind this will encourage them to exercise the powers conferred on them by article 1195 with the utmost caution, a caution which they have already shown when similar powers were conferred on them in 1975 in relation to penalty clauses. Provided that the courts use their powers with foresight and restraint, the 'classic and modern philosophy of contract law' will not be overturned. ${ }^{66}$ In practice, the real contribution of article 1195 may lie more in the importance which it attaches to the process of renegotiation by the parties than in its acceptance as a general rule of revision of contracts for imprévision in private law, not least since revision already existed in special circumstances.

\section{BÉNÉDICTE FAUVARQUE-COSSON}

Državni savetnik u Conseil d'Etat, saradnik Pravnih fakulteta i bivši profesor na Univerzitetu Panthéon Assas Pariz 2

\section{DA LI REVIZIJA NA OSNOVU IMPRÉVISION POVREĐUJE NAČELO OBAVEZNE SNAGE UGOVORA}

Rezime

Uvođenje izmene i raskida ugovora zbog nepredvidljivih promenjenih okolnosti - imprévision predstavlja jednu od najistaknutijih karakteristika reforme francuskog ugovornog prava. Cilj novog rešenja ogleda se u podsticanju stranaka da pregovorima postignu saglasnost umesto obraćanja sudu i zahteva za raskid ili sudsku reviziju. Iako sudovi generalno imaju pravo da vrše reviziju ugovora, Kasacioni sud se oslanjao na načelo obaveznosti ugovora da bi opravdao odbacivanje mogućnosti "sudske revizije zbog imprévision". U radu je analizirano pitanje da li će sudovi iskoristiti ovlašćenje koje im je dato u vidu prava na reviziju ugovora. Pored toga, učinjen je osvrt na istorijat i tok izrade rešenja koje se odnosi na imprévision, izvršena je komparativna analiza sa sličnim institutima u drugim međunarodnim izvorima prava i predstavljena relevantna sudska praksa.

Ključne reči: imprévision, nepredvidljive promenjene okolnosti, viša sila, hardship, sudska revizija

\footnotetext{
66 See F. Chénédé, 21.81 and references cited there.
} 
Bibliography

Almeida Prado Mauricio, 'Regards croisés sur les projets de règles relatifs à la théorie de l'imprévision en Europe', Revue internationale de droit comparé (RIDC), 2010.

Ancel François, Bénédicte Fauvarque-Cosson, Juliette Gest, Aux sources de la réforme du droit des contrats, Dalloz, Paris, 2017.

Başoğlu Başak (ed), The Effects of Financial Crises in the Binding Force of Contracts - Renegotiation, Rescission or Revision, Springer, Cham, 2016.

Bretzner Daniel, in Réforme du droit des contrats et pratique des affaires, Philippe StoffelMunck (ed.), Dalloz, Paris, 2015.

Busch Danny, Ewoud Hondius, Hugo van Kooten, Harriët Schelhaas, Wendy Schrama (eds), The Principles of European Contract Law and Dutch Law, A Commentary, Kluwer Law International, The Hague, 2002.

Carbonnier Jean, Droit civil. Introduction, 27th edn, PUF, Paris, 2002.

Carbonnier Jean, Essais sur les lois, Defrénois, Paris, 1979.

Chantepie Gaël, Mathias Latina, La réforme du droit des obligations. Commentaire théorique et pratiquedans l'ordre du Code civil, Dalloz, Paris, 2016.

Chénédé François, Le nouveau droit des obligations et des contrats. Consolidations. Innovations. Perspectives, Dalloz, Paris, 2016.

Garro Alejandro, 'Comparison between provisions of the CISG regarding exemption of liability for damages (Art. 79) and the counterpart provisions of the UNIDROIT Principles (Art. 7.1.7), www.cisg.law.pace.edu/cisg/principles/uni79.html, 15.08.2019. For discussions on the CISG see Harry M. Flechtner, 'Transcript of a Workshop on the Sales Convention: Leading CISG scholars discuss Contract Formation, Validity, Excuse for Hardship, Avoidance, Nachfrist, Contract Interpretation, Parol Evidence, Analogical Application, and much more, Journal of Law \& Commerce, no. 18, 1999, 191-258, and for recent developments in this area, see Catherine Kessedjian, Droit du commerce international, PUF, Paris, 2013.

Molfessis Nicolas, 'Le rôle du juge en cas d'imprévision dans la réforme du droit des contrats, Libres propos', Juris-Classeur Périodique (JCP), no. 1415, 1995.

Ole Lando et. al. (eds), Restatement of Nordic Contract Law, Djof Publishing, Copenhagen, 2016.

Olivier Deshayes, Thomas Genicon and Yves-Marie Laithier, Réforme du droit des contrats, du régime général et de la preuve des obligations. Commentaire article par article, Lexis Nexis, Paris, 2016.

Philippe Denis, 'Renégociation du contrat en cas de changement de circonstances dans la vente internationales', RDC, 2011.

Philippe Denis, Changement de circonstances et bouleversement de l'économie contractuelle, Bruylant, Bruxelles, 1986. 
Philippe Denis, French and Belgian reports, in Unexpected Circumstances in EuropeanContract Law, Ewoud Hondius, Hans C. Grigoleit (eds.), Cambridge University Press, Cambridge, 2011.

Philippe Denis, 'Le bouleversement de l'économie contractuelle en droit belge', Revue de Droit International et de Droit Comparé (RDIDC), no 2, 2015.

Philippe Malaurie, Laurent Aynès and Philippe Stoffel-Munck, Droit des obligations, 8th edn, LDGJ, Paris, 2016.

Philippe Stoffel-Munck, 'Limprévision et la réforme des effets du contrat', RDC hors-série, 2016.

Solène Rowan, The New French Law of Contract, Cambridge University Press, Cambridge, 2017.

Tallon Denis, 'Réflexions comparatives', in La modification du contrat au cours de son exécution en raison de circonstances nouvelles, René Rodière (ed), Pedone, Paris, 1984.

Thierry Revet, 'Le juge et la révision du contrat', Revue des contrats (RDC), 2016.

Vincent Heuzé, La vente internationale de marchandises, LGDJ, Paris, 2000.

Witz Claude, 'Droit uniforme de la vente internationale de marchandises: panorama 2004', Recueil Dalloz, 2005.

Yeung Horace, Huang Flora, 'Certainty over Clemency: English Contract Law in the Face of Financial Crisis', in The Effects of Financial Crises in the Binding Force of Contracts-Renegotiation, Rescission or Revision, Başak Başoğlu (ed), Springer, Cham, 2016.

Zweiger Konrad, Hein Kötz, An Introduction to Comparative Law, 3rd edn, ClarendonPress, Oxford, 1998.

Article history

Received: 30.08.2019.

Accepted: 24.09.2019. 